\title{
PEMBERDAYAAN MASYARAKAT
}

\section{MELALUI PENERAPAN TEKNOLOGI DAN MANAJEMEN}

PADA UNIT USAHA RUMAH TANGGA PERIKANAN

DI DESA TOOLAWAWO KECAMATAN LALONGGASUMEETO KABUPATEN KONAWE

Nurdiana $A^{1}$, Sarini Yusuf ${ }^{2}$, Naslina Alimina ${ }^{3}$

1]urusan Agrobisnis Perikanan FPIK-UHO, email: nurdiana@uho.ac.id

2 Jurusan Agrobisnis Perikanan FPIK-UHO, email: sariniyusuf@uho.ac.id

3Program Studi Perikanan Tangkap FPIK-UHO, email: naslinawilliam@uho.ac.id Jl. HEA Mokodompit No.1 Kampus Bumi Tridharma Anduonohu, Kendari 93232.

*Penulis Korespondensi: nurdiana@uho.ac.id

Sejarah Artikel:

Dikirim:

01 Oktober 2019

Diterima:

12 Oktober 2019

Diterbitkan:

31 Januari 2020

\begin{abstract}
ABSTRAK
Desa Toolawawo Kecamatan Lalonggasumeeto Kabupaten Konawe memiliki potensi perikanan dan kelautan yang sangat melimpah, diantaranya perikanan tangkap, perikanan budidaya, pengolahan hasil perikanan. Saat ini sebagian besar pelaku usaha di Desa Toolawawo masih menerapkan sistem tradisional dalam memanfaatkan sumberdaya perikanan. Fokus mitra sasaran pada kegiatan pengabdian kali ini adalah pelaku unit usaha penangkapan ikan dan pengasapan ikan. Permasalahan mitra yang berhasil diidentifikasi adalah pengetahuan dan informasi belum lengkap bagaimana penggunaan teknologi dalam memproduksi ikan asap yang mampu meningkatkan profit dan efisiensi usaha, kemudian rendahnya atau kurangnya informasi, pengetahuan dan kemampuan oleh mitra sasaran terkait sistem manajemen/pembukuan sederhana dalam menjalankan usahanya. Prosedur kerja dari kegiatan pengabdian dimulai dari kegiatan non-fisik, meliputi pembimbingan dan penyuluhan sebagai sarana transfer informasi dan pengetahuan mengenai teknologi pengasapan ikan. Metode pelaksanaan penyuluhan dilakukan secara berkelompok berdasarkan jenis unit usaha yang dijalankan oleh pelaku usaha. Selanjutnya kegiatan fisik dilakukan melalui pembuatan alat pengasapan dan pendampingan dengan pendekatan partisipatif. Kegiatan sosialisasi dan pelatihan serta pendampingan terhadap pelaku/unit usaha perikanan yang ada di Desa Toolawawo berjalan efektif dan berdampak positif. Terbukti dengan adanya peningkatan pengetahuan dan keterampilan khususnya dalam penggunaan teknologi pengasapan ikan dan keterampilan menyusun pembukuan sederhana. Sehingga penerapan teknologi dan penguasaan manajemen usaha mampu menghasilkan keuntungan usaha yang maksimal dan berkelanjutan
\end{abstract}

Kata kunci : usaha, perikanan, keuntungan, teknologi 


\section{PENDAHULUAN}

\section{Analisis Situasi}

Indonesia merupakan salah satu negara kepulauan terbesar di dunia. Sebagai negara kepulauan terbesar. Indonesia menyandang status sebagai negara poros maritim. Indonesia memiliki 34 (tiga puluh empat) provinsi, salah satunya provinsi Sulawesi Tenggara. Luas wilayah propinsi Sulawesi Tenggara adalah $38.140 \mathrm{~km}^{2}$ atau $3.814 .000 \mathrm{Ha}$, sedangkan wilayah lautnya seluas $110.000 \mathrm{~km}^{2}$. Dengan memiliki luas seperti itu, maka Sulawesi Tenggara menyimpan banyak potensi di darat maupun di laut untuk setiap kabupatennya.

Kabupaten Konawe merupakan kabupaten yang berada dibawah administrasi Provinsi Sulawesi Tenggara dan Luas wilayah daratan (setelah dikeluarkan Konawe Kepulauan) sebesar 580.073 Ha atau 5.800,73 $\mathrm{km}^{2}$ atau 15,21 persen dari luas wilayah daratan Sulawesi Tenggara. Kabupaten Konawe terbagi 23 Kecamatan yang tersebar di 337 desa/kelurahan.

Salah satu desa yang termasuk dalam wilayah Kabupaten Konawe adalah Desa Toolawawo, yang memiliki topografi pegunungan dan terletak disepanjang pesisir pantai Kecamatan Lalolnggasumeeto. Desa Toolawawo memiliki potensi perikanan tangkap meliputi ikan pelagis dan ikan demersal, perikanan budidaya meliputi budidaya ikan di karamba jaring apung (KJA), karamba jaring tancap (KJT), serta budidaya rumput laut, pengolahan ikan menjadi ikan asap. Total jumlah penduduk sebanyak 490 jiwa dengan jumlah 115 kepala keluarga (KK). Jumlah pelaku usaha perikanan tangkap sebanyak 23 orang atau sekitar 4,6\% dari keseluruhan warga Desa Toolawawo. Pelaku usaha pengumpul sebanyak 3 orang dan pelaku usaha pengasapan ikan sebanyak 3 orang yang aktif beroperasi hingga saat ini. Unit usaha perikanan tangkap seluruhnya dijalankan oleh kepala keluarga, sedangkan kegiatan pengolahan ikan menjadi ikan asap dilakukan oleh kaum wanita atau istri nelayan.

Pelaku usaha perikanan yang berdomisili di Desa Toolawawo sekarang ini masih termasuk skala usaha mikro dengan permodalan dan omset sekitar $\geq 200$ juta. Sehingga operasional usaha juga masih dilakukan secara tradisional. Namun dalam menjalankan aktivitas ekonomi tersebut, terdapat banyak kendala yang menjadi permasalahan khususnya mitra sasaran, diantaranya rendahnya atau kurangnya informasi dan pengetahuan oleh mitra sasaran terkait proses penangkapan yang menjaga mutu produk ikan yang menjadi bahan baku ikan asap, pengetahuan dan informasi belum lengkap bagaimana memproduksi ikan asap yang mampu meningkatkan profit/keuntungan dan efisiensi usaha serta rendahnya keinginan dan kemampuan dalam manajemen usaha untuk usaha yang berkelanjutan (Nurdiana dan Sarini $Y, 2017)^{2}$.

Berdasarkan kendala tersebut, maka rumusan permasalahan yang terdapat pada mitra sasaran adalah :

a. Rendahnya pengetahuan dan informasi yang dimiliki oleh pelaku usaha perikanan tangkap 
b. Kurangnya pengetahuan dan informasi serta keterampilan dalam menggunakan teknologi pengasapan ikan yang lebih efesien dan berdaya saing

c. Kurangnya pengetahuan dan keterampilan serta keinginan pelaku usaha dalam manajemen usaha, untuk memperoleh profit yang optimal

\section{Solusi Permasalahan}

Solusi yang ditawarkan untuk permasalahan yang dhadapi oleh pelaku usaha ikan asap di Desa Toolawawo agar usaha berkelanjutan melalui kegiatan pemberdayaan masyarakat adalah memberikan informasi dan pendampingan bagaimana melakukan penangkapan ikan yang tidak merusak fisik ikan dan penanganan pasca panen yang tepat. Karena hal tersebut sangat mempengaruhi kualitas ikan asap yang dihasilkan. Kemudian memberikan informasi tentang penggunaan teknologi pengasapan yang efesien dan berdaya saing. Melakukan pendampingan kepada pelaku usaha ikan asap mengenai pembukuan usaha sebagai bagian dari manajemen usaha untuk mengoptimalkan profit usaha rumah tangga.

\section{Tujuan dan Manfaat Kegiatan}

Adapun tujuan dari kegiatan pengabdian ini adalah :

a. Meningkatkan pengetahuan dan informasi yang dimiliki oleh pelaku usaha perikanan tangkap

b. Meningkatkan pengetahuan dan informasi serta keterampilan dalam menggunakan teknologi pengasapan ikan yang lebih efesien dan berdaya saing

c. Meningkatkan pengetahuan pelaku usaha dan keterampilan serta keinginan pelaku usaha dalam manajemen usaha, untuk memperoleh profit yang optimal

Sedangkan manfaat yang diperoleh dari terlaksananya kegiatan pengabdian ini adalah bahwa kegiatan tersebut menjadi kegiatan yang memberikan inovasi baru bagi pelaku usaha perikanan, yang diharapkan mampu memberikan dampak kepada pola pikir dan pola perilaku dari pelaku usaha perikanan menuju kemandirian dan kesejahteraan yang berkelanjutan.

\section{Luaran Pengabdian}

Luaran terdiri atas dua yaitu luaran wajib dan luaran tambahan. Adapun luaran wajib yang ditargetkan dan yang tercapai hingga saat ini pada kegiatan KKN-PPM 2019 adalah seperti pada Tabel 1 berikut :

Tabel 1. Luaran wajib kegiatan pengabdian KKN-PPM Tahun 2019

\begin{tabular}{|c|l|c|l|}
\hline No & \multicolumn{1}{|c|}{ Jenis Luaran } & $\begin{array}{c}\text { Status } \\
\text { target } \\
\text { capaian }\end{array}$ & \multicolumn{1}{|c|}{ Keterangan } \\
\hline 1. & $\begin{array}{l}\text { Artikel Ilmiah Publikasi } \\
\text { ilmiah Jurnal nasional } \\
\text { ber ISSN }\end{array}$ & Terbit & $\begin{array}{l}\text { artikel Jurnal Humanoa- Jurnal I/miah } \\
\text { Pengabdian Kepada Masyarakat } \\
\text { http://uho.ac.id/index.php/anoa }\end{array}$ \\
\hline 2. & $\begin{array}{l}\text { Artikel Media Massa } \\
\text { elektronik lokal }\end{array}$ & $\begin{array}{l}\text { Sudah } \\
\text { terbit }\end{array}$ & $\begin{array}{l}\text { Detik sultra.com } \\
\text { https://detiksultra.com/warga-pesisir-konawe- } \\
\text { siap-optimalkan-pemberdayaan-usaha- } \\
\text { perikanan }\end{array}$ \\
\hline 3. & $\begin{array}{l}\text { Dokumentasi } \\
\text { pelaksanaan berupa }\end{array}$ & Upload & www.youtube.com \\
\hline
\end{tabular}




\begin{tabular}{|l|l|c|l|}
\hline & video kegiatan & & \\
\hline 4. & $\begin{array}{l}\text { Peningkatan } \\
\text { keberdayaan masyarakat } \\
\text { yakni pengetahuannya } \\
\text { meningkat }\end{array}$ & $\begin{array}{c}\text { Sudah } \\
\text { tercapai }\end{array}$ & Menjadi indikator ketercapaian program \\
\hline
\end{tabular}

Sedangkan luaran tambahan dari kegiatan program KKN-PPM 2019 ini adalah terlihat pada Tabel 2.

Tabel 2. Luaran tambahan kegiatan pengabdian KKN-PPM Tahun 2019

\begin{tabular}{|c|l|c|l|}
\hline No & \multicolumn{1}{|c|}{ Jenis Luaran } & $\begin{array}{c}\text { Status } \\
\text { target } \\
\text { capaian }\end{array}$ & \multicolumn{1}{c|}{ Keterangan } \\
\hline 1. & $\begin{array}{l}\text { Desain Produk } \\
\text { Industi }\end{array}$ & $\begin{array}{c}\text { Produk/ alat } \\
\text { pengasapan } \\
\text { ikan }\end{array}$ & $\begin{array}{l}\text { Menjadi langkah awal dalam persiapan } \\
\text { produk yang bernilai ekonomi tinggi } \\
\text { dan berdaya saing }\end{array}$ \\
\hline 2. & $\begin{array}{l}\text { Keterampilan } \\
\text { meningkat }\end{array}$ & $\begin{array}{c}\text { Sudah } \\
\text { tercapai }\end{array}$ & $\begin{array}{l}\text { Indikator ketercapaian program } \\
\text { dengan mengevaluasi perubahan dan } \\
\text { peningkatan keterampilan kelompok } \\
\text { sasaran melalui memberian/pengisian } \\
\text { angket evaluasi ketercapaian program }\end{array}$ \\
\hline
\end{tabular}

\section{METODE PELAKSANAAN}

\section{Tempat dan Waktu}

Kegiatan pengabdian KKN-PPM ini dilaksanakan di Desa Toolawawo Kecamatan Lalonggasumeeto Kabupaten Konawe Provinsi Sulawesi Tenggara. Kegiatan pemberangkatan mahasiswa ke lokasi dilaksanakan pada Tanggal 5 Juli 2019, kemudian penarikan pada Tanggal 5 Agustus 2019.

\section{Kerangka Pemecahan Masalah}

Berdasarkan identifikasi permasalahan mitra, baik dalam hal aspek produksi maupun manajemen usaha, maka pendekatan atau metode yang akan dilakukan kepada pelaku usaha perikanan di Desa Toolawawo Kecamatan Lalonggasumeeto Kabupaten Konawe dapat diuraikan sebagai berikut:

Metode pelaksanaan program pengabdian masyarakat ini digunakan metode PALS (Participatory Action Learning System). Metode pengabdian dengan pendekatan PALS merupakan metode pemberdayaan masyarakat dalam pembangunan kewilayahan dengan tahapan-tahapan kegiatan:

a. Tahap penyadaran (Awareness) merupakan tahap inisiasi untuk menyadarkan masyarakat agar memahami kondisi dan potensi wilayah, serta usaha produktif yang dapat meningkatkan tarap hidup

b. Tahap pengkapasitasan (participating) adalah tahap pelibatan partisipasi aktif dan pendampingan pada masyarakat untuk membangun, mengelola, dan membesarkan usaha produktifnya, yaitu melalui kegiatan pelatihan dan pendampingan 
c. Tahapan pelembagaan (institutionalization) adalah mewadahi usaha produktif masyarakat pada suatu kelompok institusi yang dapat memudahkan proses belajar, transfer IPTEKS, pemasaran dan jaminan legalitas usaha.

\section{Khalayak Sasaran/Mitra Kegiatan}

Khalayak sasaran atau mitra dari kegiatan pengabdian ini adalah pelaku usaha perikanan yang ada di Desa Toolawawo Kecamatan Lalonggasumeeto yang terdiri dari pelaku usaha perikanan tangkap, jumlah pelaku usaha perikanan tangkap sebanyak 23 orang atau sekitar $4,6 \%$ dari keseluruhan warga Desa Toolawawo. Pelaku usaha pengumpul sebanyak 3 orang dan pelaku usaha pengasapan ikan sebanyak 3 orang.

\section{Realisasi Pemecahan Masalah \\ a. Persiapan dan Pembekalan Mekanisme Pelaksanaan Kegiatan KKN-PPM}

Kegiatan pembelajaran pemberdayaan masyarakat ini disatukan dengan kegiatan KKN Universitas Halu Oleo. Program KKN dengan bobot 4 sks ini merupakan program tahunan yang masuk dalam kurikulum yang wajib diadakan di semua fakultas lingkup UHO. Mekanisme pendaftaran KKN-PPM ini dilaksanakan secara terpusat, yaitu melalui lembaga mata kuliah dasar (MKU) dan dilaporkan ke lembaga penelitian dan pengabdian masyarakat (LPPM) UHO. Mahasiswa yang sudah mendapat persetujuan dari jurusan terlebih dahulu mendaftar kepada dosen penerima hibah KKN-PPM. Selanjutnya melalui dosen tersebut mahasiswa didaftar untuk ikut dalam program KKN yang sebelumnya telah memprogram KKN di siakad terlebih dahulu.

\section{Materi Persiapan dan Pembekalan KKN-PPM yang perlu diberikan Kepada Mahasiswa}

Materi persiapan yang berupa pembekalan KKN-PPM akan dilakukan sebelum rombongan KKN-PPM berangkat di lokasi yang telah ditentukan. Pembekalan diberikan oleh Ketua Jurusan dari masing-masing Fakultas dan dosen pembimbing KKN-PPM. Ketua Jurusan dalam hal ini memberikan pembekalan seputar bagaimana membawa diri dan berinteraksi bersama masyarakat. Hal tersebut diberikan dengan tujuan sebagai pembekalan kepada mahasiswa nantinya jika berhadapan dengan masyarakat umum yang tentunya karakter dan pembawaannya sangat berbeda dengan kehidupan kampus.

Pembimbing KKN-PPM bertugas memberikan bimbingan teknis seputar kegiatan pengabdian yang nantinya akan mereka lakukan dilakukan di desa. Bimbingan yang diberikan dalam hal ini seputar pelaksanaan sosialisasi/pelatihan/pendampingan teknik penangkapan ikan dan penanganan ikan dikapal, pemberdayaan pelaku usaha dalam hal mengolah produk ikan asap melalui teknologi yang efesien, serta melatih sistem manajemen usaha rumah tangga perikanan untuk bisnis yang berkelanjutan

\section{b. Metode Pelaksanaan}

\section{Sosialisasi/pendampingan Metode Penangkapan dan Penanganan Ikan di Kapal}

Kegiatan pelatihan dan pendampingan metode penangkapan ikan dan penanganan ikan di kapal, sangat penting untuk dilakukan kepada kelompok masyarakat sasaran di 
Desa Toolawawo. Hal tersebut penting karena berdasarkan identifikasi permasalahan pada kelompok mitra pada skema program PKM Tahun 2017, bahwa kualitas dan mutu ikan asap yang dihasilkan oleh pelaku usaha ikan asap tergolong rendah dan mudah rusak. Salah satu penyebabnya adalah kesalahan teknik dan metode yang dilakukan terhadap hasil tangkapan yang tidak sesuai standar, sehingga menghasilkan ikan yang tergolong rusak atau cacat fisik.

\section{Pelatihan Manajemen Usaha}

Kegiatan pelatihan manajemen usaha atau pembukuan sederhana terhadap kegiatan unit usaha rumah tangga juga sangat penting dilakukan, dalam rangka untuk mengoptimalkan profit dan usaha yang berkelanjutan dan layak untuk dilanjutkan.

\section{Pelatihan/Pendampingan Penggunaan Teknologi Pengasapan Ikan}

Pelatihan penggunaan teknologi pengasapan ikan dilakukan untuk meningkatkan kapasitas pelaku usaha ikan asap, dan meningkatkan efisiensi usaha, dalam menghasilkan produk yang berdaya saing dan bernilai ekonomi tinggi.

\section{Indikator Keberhasilan}

Guna mengukur ketercapaian program, maka dilakukan indikator ketercapaian program. Ada 7 (tujuh) indikator yang diharapkan dapat dipenuhi dalam kegiatan ini yang selengkapnya terdapat pada Tabel 3.

Tabel 3. Indikator Keberhasilan Program KKN-PPM 2019

\begin{tabular}{|c|c|c|c|c|}
\hline No & Target & $\begin{array}{l}\text { Sebelum adanya } \\
\text { KKN-PPM }\end{array}$ & $\begin{array}{c}\text { Sebelum adanya } \\
\text { KKN-PPM }\end{array}$ & Ket \\
\hline 1. & $\begin{array}{l}\text { Kelompok sasaran } \\
\text { dapat mengetahui } \\
\text { metode } \\
\text { penangkapan ikan } \\
\text { yang tepat }\end{array}$ & $\begin{array}{l}\text { Kelompok sasaran tidak } \\
\text { mengetahui bagaimana } \\
\text { metode penangkapan } \\
\text { ikan yang tepat }\end{array}$ & $\begin{array}{l}\text { Kelompok sasaran } \\
\text { telah mengetahui } \\
\text { bagaimana metode } \\
\text { penangkapan ikan } \\
\text { yang tepat } \\
\end{array}$ & Tercapai \\
\hline 2. & $\begin{array}{l}\text { Kelompok sasaran } \\
\text { dapat mengetahui } \\
\text { kebijakan dan } \\
\text { undang undang } \\
\text { tentang perikanan } \\
\text { tangkap yang } \\
\text { berlaku di Indonesia }\end{array}$ & $\begin{array}{l}\text { Kelompok sasaran } \\
\text { belum mengetahui } \\
\text { kebijakan dan undang } \\
\text { undang tentang } \\
\text { perikanan tangkap yang } \\
\text { berlaku di Indonesia }\end{array}$ & $\begin{array}{l}\text { Kelompok sasaran } \\
\text { telah mengetahui } \\
\text { kebijakan dan } \\
\text { undang undang } \\
\text { tentang perikanan } \\
\text { tangkap yang } \\
\text { berlaku di Indonesia }\end{array}$ & Tercapai \\
\hline 3. & $\begin{array}{l}\text { Kelompok sasaran } \\
\text { dapat mengetahui } \\
\text { metode penanganan } \\
\text { ikan di kapal yang } \\
\text { tidak merusak fisik } \\
\text { ikan }\end{array}$ & $\begin{array}{l}\text { Kelompok sasaran } \\
\text { belum mengetahui } \\
\text { metode penanganan } \\
\text { ikan di kapal yang tidak } \\
\text { merusak fisik ikan }\end{array}$ & $\begin{array}{l}\text { Kelompok sasaran } \\
\text { telah mengetahui } \\
\text { metode penanganan } \\
\text { ikan di kapal yang } \\
\text { tidak merusak fisik } \\
\text { ikan } \\
\end{array}$ & Ter \\
\hline 4. & $\begin{array}{l}\text { Kelompok sasaran } \\
\text { dapat mengetahui } \\
\text { salah satu penyebab } \\
\text { mutu ikan asap } \\
\text { rendah adalah }\end{array}$ & $\begin{array}{l}\text { Kelompok sasaran } \\
\text { belum mengetahui } \\
\text { salah satu penyebab } \\
\text { mutu ikan asap rendah } \\
\text { adalah penanganan } \\
\end{array}$ & $\begin{array}{l}\text { Kelompok sasaran } \\
\text { telah mengetahui } \\
\text { salah satu penyebab } \\
\text { mutu ikan asap } \\
\text { rendah adalah } \\
\end{array}$ & Tercapai \\
\hline
\end{tabular}




\begin{tabular}{|c|c|c|c|c|}
\hline & $\begin{array}{l}\text { penanganan ikan } \\
\text { hasil tangkapan }\end{array}$ & ikan hasil tangkapan & $\begin{array}{l}\text { penanganan ikan } \\
\text { hasil tangkapan }\end{array}$ & \\
\hline 5. & $\begin{array}{l}\text { Kelompok sasaran } \\
\text { dapat mengetahui } \\
\text { metode pengasapan } \\
\text { ikan yang efesien } \\
\text { dan berdaya saing } \\
\end{array}$ & $\begin{array}{l}\text { Kelompok sasaran tidak } \\
\text { mengetahui metode } \\
\text { pengasapan ikan yang } \\
\text { efesien dan berdaya } \\
\text { saing }\end{array}$ & $\begin{array}{l}\text { Kelompok sasaran } \\
\text { telah mengetahui } \\
\text { metode pengasapan } \\
\text { ikan yang efesien } \\
\text { dan berdaya saing }\end{array}$ & Tercapai \\
\hline 6. & $\begin{array}{l}\text { Kelompok sasaran } \\
\text { dapat mengetahui } \\
\text { metode manajemen } \\
\text { usaha perikanan } \\
\text { atau pembukuan } \\
\text { sederhana }\end{array}$ & $\begin{array}{l}\text { Kelompok sasaran tidak } \\
\text { mengetahui metode } \\
\text { manajemen usaha } \\
\text { perikanan atau } \\
\text { pembukuan sederhana }\end{array}$ & $\begin{array}{l}\text { Kelompok sasaran } \\
\text { telah mengetahui } \\
\text { metode manajemen } \\
\text { usaha perikanan } \\
\text { atau pembukuan } \\
\text { sederhana }\end{array}$ & Tercapai \\
\hline 7. & $\begin{array}{l}\text { Kelompok sasaran } \\
\text { dapat mengetahui } \\
\text { bagaimana efesiensi } \\
\text { usaha dalam } \\
\text { mengoptimalkan } \\
\text { profit }\end{array}$ & $\begin{array}{l}\text { Kelompok sasaran tidak } \\
\text { mengetahui bagaimana } \\
\text { efesiensi usaha dalam } \\
\text { mengoptimalkan profit }\end{array}$ & $\begin{array}{l}\text { Kelompok sasaran } \\
\text { telah mengetahui } \\
\text { bagaimana efesiensi } \\
\text { usaha dalam } \\
\text { mengoptimalkan } \\
\text { profit }\end{array}$ & Tercapai \\
\hline
\end{tabular}

\section{Metode Evaluasi}

Adapun evaluasi yang dilakukan diantaranya yakni : evaluasi terhadap pengetahuan, peningkatan keterampilan, dan sosial ekonomi.

a. Evaluasi perubahan pengetahuan. Evaluasi ini dilakukan memberikan beberapa pertanyaan dalam kuisioner terkait dengan pengetahuan pelaku usaha terhadap kegiatan penangkapan ikan dan penanganan ikan dikapal, penggunaan teknologi pengasapan ikan, manajemen usaha khususnya pembukuan sederhana, yang selanjutnya hasil kuisioner tersebut akan dijelaskan secara deskriptif untuk melihat kemajuan yang dicapai oleh kelompok pelaku usaha perikanan.

b. Evaluasi keterampilan. Evaluasi ini dilakukan dengan memantau kegiatan kelompok pelaku usaha perikanan dalam membuat menerapkan teknik atau metode penangkapan ikan dan penanganan ikan dikapal, keterampilan menggunakan teknologi pengasapan ikan yang lebih baik, serta keterampilan dalam menerapkan system manajemen usaha khususnya pembukuan sederhana.

c. Evaluasi sosial ekonomi. Observasi dilakukan di wilayah sasaran jangka waktu \pm 1 bulan sebelum program berakhir. Kontribusi ekonomi program ini diharapkan memberikan peningkatan yang signifikan terhadap pendapatan unit usaha rumah tangga perikanan, sedangkan kontribusi sosial yakni terciptanya lapangan pekerjaan di desa khususnya desa pesisir, serta kemampuan pelaku usaha untuk berwirausaha secara mandiri dan berkelanjutan 


\section{HASIL DAN PEMBAHASAN \\ 1. Kegiatan Pelatihan/Pendampingan Metode Penangkapan Ikan dan Penanganan Ikan di Kapal}

Kegiatan pembelajaran dan pemberdayaan masyarakat sasaran dalam hal teknik atau metode penangkapan ikan serta penanganan ikan di kapal, dilakukan pertama tama dengan memberikan pemahaman dan pengetahuan serta informasi mengenai peraturan dan undang-undang yang berlaku di Indonesia terkait dengan penangkapan ikan. Pelaku usaha perikanan tangkap yang ada di Desa Toolawawo berjumlah 23 orang, dengan rincian bahwa alat tangkap yang digunakan terdiri dari pancing tonda, rawai serta jaring insang.
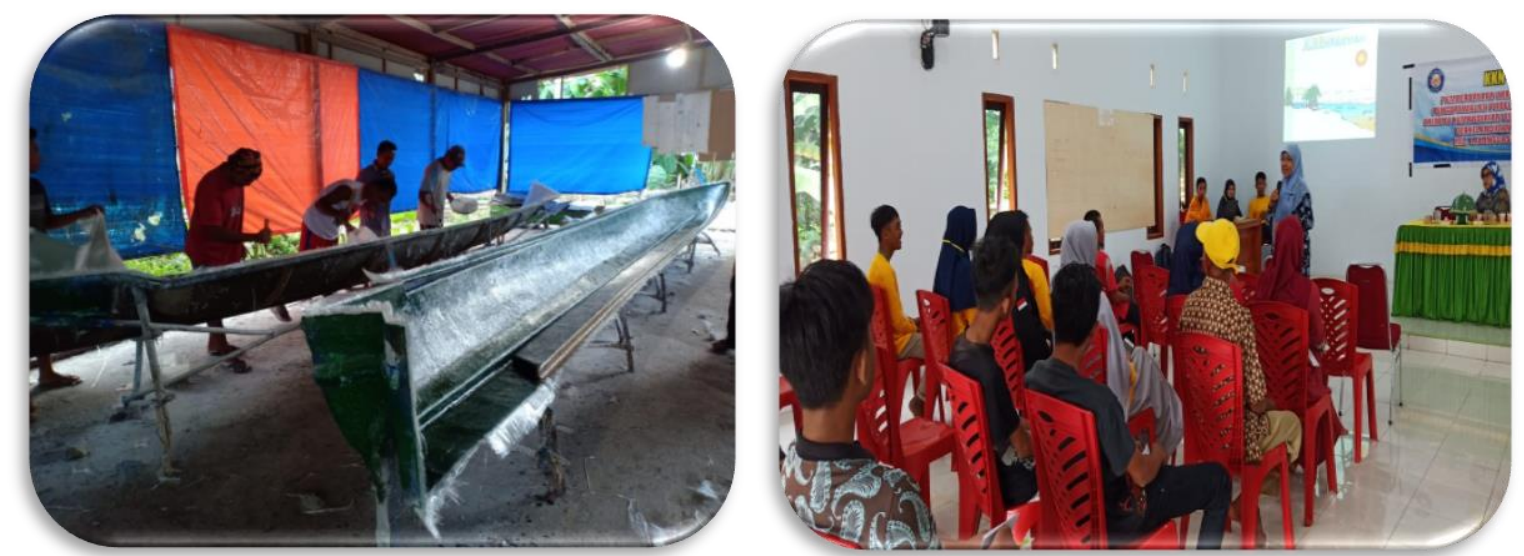

Gambar 1. Kegiatan pelatihan dan pendampingan Teknologi Penangkapan Ikan dan Penanganan Ikan di Kapal

Pada unit usaha penangkapan ikan, pelaku usaha memperoleh tambahan pengetahuan, informasi dan keterampilan tentang proses penangkapan ikan dan penanganan ikan dikapal. Kegiatan penangkapan ikan yang tepat akan menghasilkan produk ikan yang mempengaruhi hasil ikan asap, sehingga akan menghasilkan produk ikan asap yang memiliki harga jual tinggi dan tingkat daya tahan yang lama.

\section{Kegiatan Manajemen Usaha Perikanan}

Proses pelaksanaan pembelajaran berupa pelatihan dan pendampingan manajemen usaha atau pembukuan sederhana dilakukan dalam rangka peningkatan pengetahuan dan keterampilan pelaku usaha perikanan dalam mengefesienkan dan mengoptimalkan keuntungan/profit unit usaha rumah tangga yang mereka jalankan 

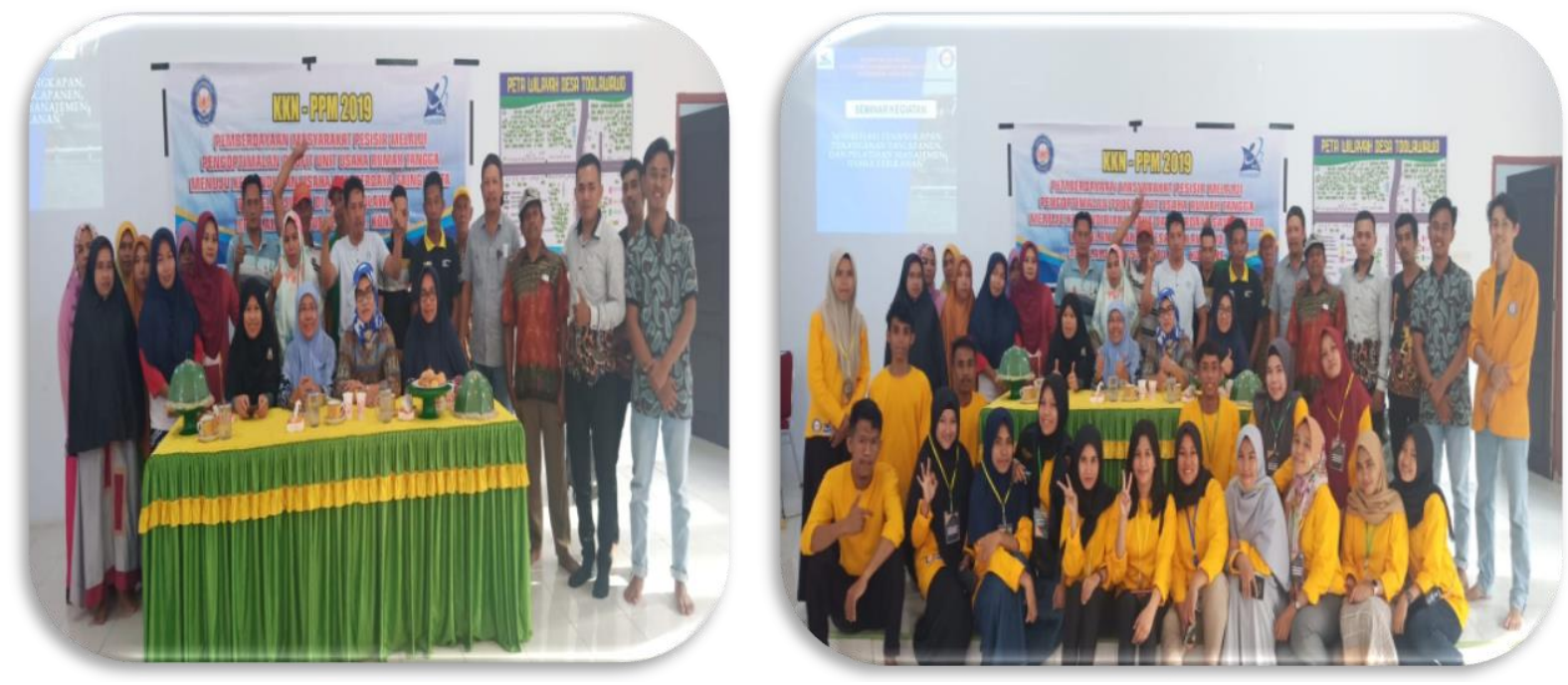

Gambar 2. Kegiatan Proses Pelatihan Manajemen Usaha/Pembukuan sederhana

Sistem manajemen usaha sangat diperlukan dalam setiap unit usaha khususnya usaha perikanan. Hal tersebut disebabkan karena manajemen usaha membantu dalam merencanakan, mengontrol dan mengevaluasi usaha yang dijalankan, untuk memperoleh tujuan usaha yaitu mengoptimalkan profit dari unit usaha yang berkelanjutan. Pelatihan dan pendampingan yang telah dilaksanakan telah memberikan pengaruh nyata terhadap pola perilaku dan pola pikir dari pelaku usaha.

\section{Kegiatan Pelatihan/Pendampingan Penggunaan Teknologi Pengasapan}

Ikan

Pelaksanaan pelatihan dan pendampingan penggunaan alat pengasapan ikan telah dilaksanakan. Hasil olahan ikan asap menggunakan alat modern atau teknologi sangat berbeda dengan hasil olahan ikan asap yang diolah secara sederhana

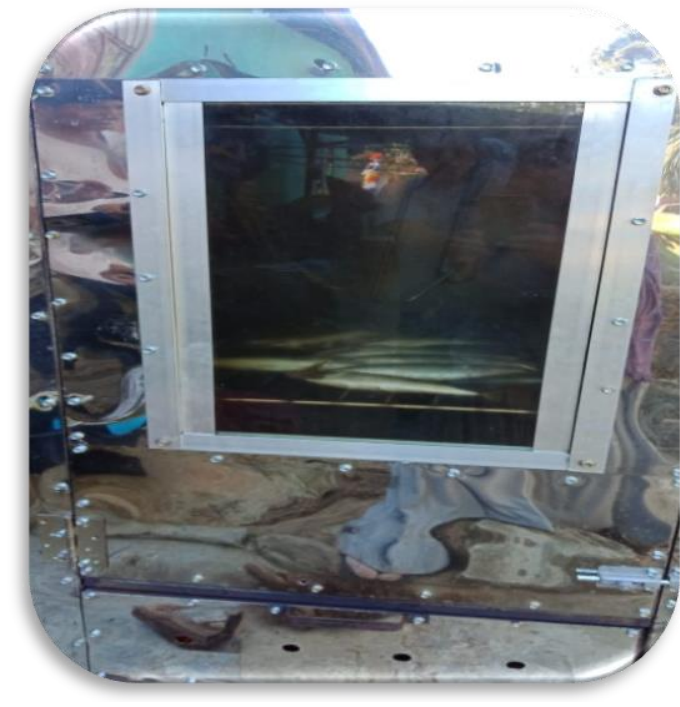

(a)

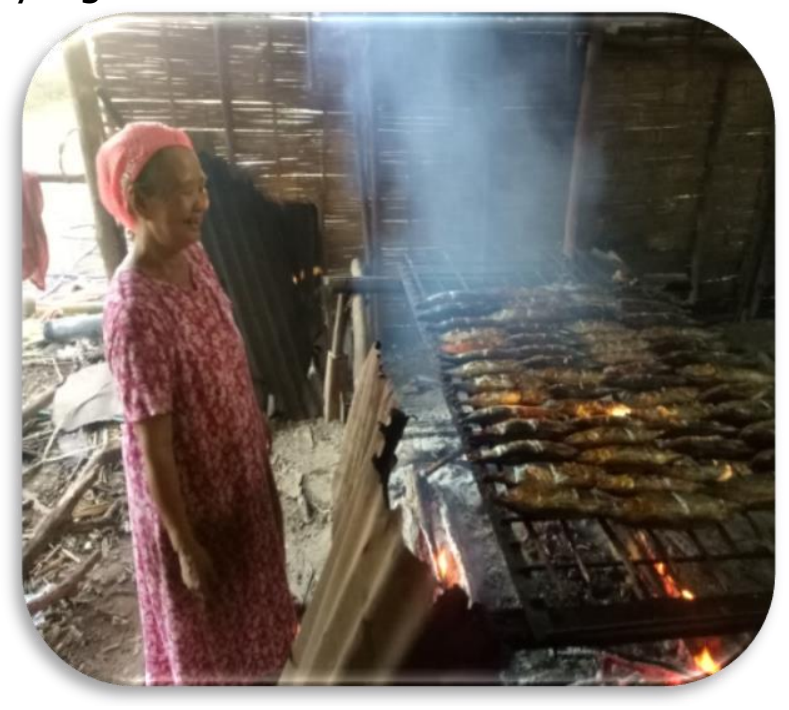

(b)

Gambar 3. (a) Teknologi Pengasapan Ikan, (b) Pengasapan ikan secara sederhana 
Berdasarkan hasil pengabdian bahwa terdapat beberapa keunggulan penggunaan teknologi pengasapan ikan diantaranya : Teknologi ikan asap terbukti memiliki keunggulan yaitu tingkat higienitas produk tinggi dan produk yang dihasilkan tidak mudah rusak, mengefesienkan waktu produksi dari 5 jam menjadi 3 jam, meminimalisir polusi udara dan menghemat bahan bakar, tidak membutuhkan tempat produksi yang luas tapi dapat menghasilkan hasil yang lebih banyak, memudahkan proses produksi (pada saat membolak balikkan ikan tidak pindah tempat), dan produk ikan asap yang dihasilkan dapat bertahan lama.

\section{KESIMPULAN}

\section{KESIMPULAN DAN SARAN}

Program pembelajaran dan pemberdayaan masyarakat yang merupakan pengabdian TIM FPIK UHO dapat terlaksana dengan baik.

\section{SARAN}

Diharapkan program KKN-PPM selanjutnya lebih bersinergi dan sejalan dengan pemerintah desa setempat sehingga bisa lebih optimal hasil yang diperoleh sesuai dengan harapan semua pihak.

\section{DAFTAR PUSTAKA}

Adawyah, R. 2008. Pengolahan dan Pengawetan Ikan. Bumi Aksara. Jakarta BPS Konawe. 2017. Konawe dalam Angka. BPS Konawe. 93 hal.

Fadhila Hukmi. 2010. Analisis Kelayakan Pengembangan Usaha Pengolahan Ikan Asap (Studi Kasus pada Aneka Ikan Asap IACHI Petikan Cita Halus (PCH), Desa Raga Jaya, Kecamatan Citayam, Kabupaten Bogor, Jawa Barat). Fakultas Ekonomi Dan Manajemen Institut Pertanian Bogor.174 hal.

Fronthea Swastawati. 2011. Studi Kelayakan Dan Efisiensi Usaha Pengasapan Ikan Dengan Asap Cair Limbah Pertanian di Kota Semarang. akultas Perikanan dan Ilmu Kelautan Universitas Diponegoro Semarang

Indo Yama Nasarudin. 2013. Analisis Kelayakan Ekonomi dan Keuangan Usaha Ikan Lele Asap di Pekanbaru. Universitas Padjajaran. Jurnal Etikonomi Vol. 12 No. 2 Oktober 2013

Kusuma, P.T.W. 2010. Financial Analysis Pengembangan Usaha Kecil Menengah (UKM) Produsen Flakes Ubi Jalar (Emergency Food) (Studi Kasus UKM Mandiri Pangan Mapan Makmur, Gunung Kidul). Proceeding Seminar on Application and Research in Industrial Technology 2010 (SMART) Tahun 2010 : C1-C6. Yogyakarta, 29 Juli 2010 : Universitas Gadjah Mada Yogyakarta

Nurdiana A dan Sarini Yusuf. 2017. Laporan Pengabdian kepada Masyarakat (Ibm) iptek bagi kelompok usaha pengasapan ikan guna menghasilkan produk yang berdaya saing. Kendari 


\section{UCAPAN TERIMAKASIH}

Terima kasih kami ucapkan kepada Direktorat Riset dan Pengabdian Masyarakat, Direktorat Jenderal Penguatan Riset dan Pengembangan, Kementerian Riset, Teknologi, dan Pendidikan Tinggi. Juga kepada Lembaga Penelitian Dan Pengabdian Masyarakat Universitas Halu Oleo, Pemerintah Daerah Desa Toolawawo serta masyarakat Desa Toolawawo serta seluruh pihak yang telah berpartisipasi dan membantu kelancaran kegiatan pengabdian kami ini. 